\title{
Assessment of rheological and quality characteristics of bread made by the addition of ginger powder in wheat flour
}

\author{
Adnan AMJAD ${ }^{1 *}$ (D), Muhammad SOHAIB ${ }^{2}$, Haq NAWAZ 3 , Muhammad Sameem JAVED ${ }^{1}$, Mohibullah SHAH ${ }^{3}$, \\ Faiz-Ul-Hassan $\mathrm{SHAH}^{4}$, Muhammad Rizwan TARIQ ${ }^{5}$, Muhammad Wasim SAJID ${ }^{6}$, Ammar Ahmed KHAN ${ }^{7}$, \\ Muhammad BILAL ${ }^{1}$, Haseeb USMAN ${ }^{1}$, Muhammad AHMAD ${ }^{8}$, Talal Majeed AHMAD ${ }^{8}$
}

\begin{abstract}
The aim of this study was to develop a bread enriched with varying level of ginger powder. Ginger powder incorporated in white flour at $0,2,4,6$ and $8 \%$ level to get a bread enriched with antioxidants and good rheological and sensorial properties. Total phenolic content (TPC) was gradually decreased with increasing percentage of ginger powder and maximum inhibition of DPPH was recorded (47.23\%) at $2 \%$ supplemented sample. Texture of supplemented bread samples was increased in terms of hardness, gumminess and chewiness as compared to control sample. Mineral contents increased in each sample with increasing percentage of ginger powder such as $\mathrm{Na}(451.69 \mathrm{mg} / \mathrm{kg}), \mathrm{Ca}(127.32 \mathrm{mg} / \mathrm{kg}), \mathrm{K}(427.61 \mathrm{mg} / \mathrm{kg}), \mathrm{Fe}(15.19 \mathrm{mg} / \mathrm{kg})$, $\mathrm{Zn}(7.04 \mathrm{mg} / \mathrm{kg})$ and $\mathrm{Cu}(3.47 \mathrm{mg} / \mathrm{kg})$ respectively. However, showed worst results regarding rheological properties with hard dough structure. Among studied samples, a range of 2-4\% ginger powder presented high antioxidants with better rheological characteristics compared with control samples.
\end{abstract}

Keywords: ginger powder; antioxidants; bread quality; texture.

Practical Application: Bakery products are good source of food to be supplemented with various ingredients. Conservation and incorporation of ginger in powder form is important to provide high value nutritional foods. The development of various concentration of ginger powder bread will provide the consumer a great choice and quality of food as well as a challenge for food industry.

\section{Introduction}

Relationship between health and food has an increasing impact on food innovation due to popularity of the concept for functional foods. Use of nutritional knowledge and its practice in developing novel food products to improve the consumer health is necessary (Peressini \& Sensidoni, 2009). In current scenario consumers prefer to eat healthier foods in order to prevent non-communicable diseases. Therefore, industry and researchers are engaged in optimizing bread making technology to improve the variety, quality, taste and availability of bakery products such as bread (Hathorn et al., 2008).

Cereal based food products such as biscuits, cakes, cookies and bread feed up large masses by providing antioxidants and other healthy compounds along with dietary fibers (Ktenioudaki \& Gallagher, 2012). Herbs are the important segment of human diet and can be use as ingredient in the formulation of bread. Besides their aesthetical value, herbs provide antimicrobial, antioxidative and preservative effects (Balestra et al., 2011). Ginger
(Zingiber officinale) is a monocotyledonous flowering plant. It belongs to Zingiberaceae family that is extensively used as spice in various foods around the world (Ali et al., 2008). Ginger contains gingerols with various health benefits and reported to lower the risk of obesity, colon cancer, arthritis and diabetes (Young et al., 2006; Bailey-Shaw et al., 2008). Ginger is an excellent source of antioxidants and many antioxidant components reflect higher activities in fermented media as investigated by various assays. Hence, other than its medicinal aspects, ginger can be used as antioxidant rich supplement (Shirin Adel \& Jamuna, 2010).

Bread is a major part of our daily intake hence; research should be carried out to explore new practices for enhancing keeping qualities of bread by incorporating natural ingredients. The aim of current study was to enriched wheat flour with ginger powder in order to get specific characteristics of bread at varying levels of ginger. Quality parameters of end product would be used as an indicators of consumer acceptance for healthier life style.

\footnotetext{
Received 09 Sept., 2020

Accepted 29 Jan., 2021

${ }^{1}$ Institute of Food Science and Nutrition, Bahauddin Zakariya University, Multan, Pakistan

${ }^{2}$ Department of Food Science and Human Nutrition University of Animal and Veterinary Sciences, Lahore, Pakistan

${ }^{3}$ Department of Biochemistry, Bahauddin Zakariya University, Multan, Pakistan

${ }^{4}$ Department of Food Science \& Technology, University College of Agriculture and Environmental Sciences, The Islamia University of Bahawalpur, Pakistan

${ }^{5}$ Institute of Agricultural Sciences, University of the Punjab, Lahore, Pakistan

${ }^{6}$ Department of Biosciences, COMSATS Institute of Information Technology, Sahiwal, Pakistan

${ }^{7}$ University institute of diet and nutritional sciences, The University of Lahore, Pakistan

${ }^{8}$ Muhammad Nawaz Shareef University of Agriculture, Multan, Pakistan

*Corresponding author: adnanamjad@bzu.edu.pk
} 


\section{Material and methods}

\subsection{Collection of fresh ginger}

Fresh ginger was collected for experimental work from the local market of Multan city and washed under tap water to remove dust, dirt and adhered material. The samples were subjected to blanching by hot water steeping for 15 second followed by immersion in potassium metabisulphite solution $(0.2 \%)$ at room temperature for $5 \mathrm{~min}$. After blanching and sulphiting, the samples were dried properly.

\subsection{Preparation of ginger powder}

The selected samples (triplicates) were chopped to small pieces and dried in an oven (Universal UN-30, Memmert) at $50 \pm 2{ }^{\circ} \mathrm{C}$ for $8 \mathrm{hr}$ up to $11 \%$ moisture content (Sangwan et al., 2014). The dried slices of ginger were grounded by using laboratory scale blender (Black \& Decker Model, BX600G) into powder and passed through $2 \mathrm{~mm}$ mesh size sieve then $1.5 \mathrm{~mm}$ accordingly, to get a fine powder. The sample was packed in polythene bags and marked for identification.

\subsection{Dough and bread preparation}

Wheat flour was enriched with ginger powder at varying level of $0,2,4,6$ and $8 \%$ respectively to form blends of mixture. A control bread sample was also prepared without addition of ginger powder. The recipe adopted for each percentage of ginger powder separately with water $250 \mathrm{~mL}$, white flour taken hard spring wheat, $(550 \mathrm{~g})$, Magimix ${ }^{\circledast}$ bread improver $(5 \mathrm{~g})$, Baker's instant dry yeast (18 g), iodized salt ( $3 \mathrm{~g}$ ) and corn oil (15 g). Straight dough method was adopted for mixing the bread ingredients. All the ingredients were added to an electric mixture (Kenwood KM250 Stand Mixer, UK) except salt. Mixing was performed for $15 \mathrm{~min}$ and thin sheet of the dough was checked to confirm proper mixing. After mixing, molding of dough was conducted followed by proofing at $40^{\circ} \mathrm{C}$ for $45-50 \mathrm{~min}$ with $80-85 \%$ relative humidity. Baking was done for $20 \mathrm{~min}$ at $210^{\circ} \mathrm{C}$ in a deck oven (CA6X, Doyon). Cooling of the baked bread was conducted at room temperature following the slicing.

\subsection{Farinograph test}

Farinograph test was carried out to determine the dough development time (min), water absorption (\%), and dough stability (min), of dough made from the various treatments under evaluation. Test was performed by using farinograph apparatus (Chopin Technologies, France) with 250 gm sample (triplicate) based on 14\% moisture content (Balestra et al., 2011).

\subsection{Mixograph test}

Rheological properties of raw material were determined by Chopin Mixolab 2, (Villeneuve-la-Garenne, France) using Chopin + protocol with the slight modification in dough weight from $70 \mathrm{gm}$ to $80 \mathrm{gm}$. In mixograph test, Mixolab curve showing the different factors: mixing time ( $\mathrm{min}$ ), water absorption (\%), dough development time (min), retrogradition $(\mathrm{Nm})$ and viscocity (Nm). This test performed using Mixolab apparatus available at Ghausia Flour and General Mills (PVT) limited in Lahore-Pakistan (Hadnađev et al., 2011).

\subsection{Total Phenolic Content (TPC)}

Sample extraction procedure was adopted as described by Chan et al. (2008) to find out phenolic contents. TPC evaluated with some modification by using Folin-Ciocalteau reagent with Gallic acid analytical grade as a standard. Gallic acid $(125 \mu \mathrm{L})$ was used as standard (control treatment) while $125 \mu \mathrm{L}$ of extracted sample was taken in $500 \mu \mathrm{L}$ distilled water having Folin-Ciocalteau reagent. After $10 \mathrm{~min}$, the mixture was added in $1.25 \mathrm{~mL}$ of $7 \%$ sodium carbonate and kept for 1 hour in the dark place. The sample absorbance was measured by using spectrophotometer (UV-Visible) at the wavelength of $760 \mathrm{~nm}$ (Balestra et al., 2011).

\subsection{2,2-diphenyl-1-picrylhydrazyl (DPPH)}

Antioxidant activity of ginger bread was determined by the DPPH (2,2-diphenyl-1-picrylhydrazyl) method. A $0.5 \mathrm{~mL}$ sample of ginger bread extract was added to $3 \mathrm{~mL}$ of DPPH solution and added to $2 \mathrm{~mL}$ of ethanol solution. Three serial dilutions of each sample of ginger bread powder was prepared in ethanol. The absorbance of DPPH at $517 \mathrm{~nm}$ was observed by Specord 200 plus spectrometer, Germany (Kelebek et al., 2009).

\subsection{Texture Profile Analysis (TPA)}

Texture of bread evaluated with a texture analyzer equipped with $5 \mathrm{Kg}$ load cell and $10 \mathrm{~mm}$ diameter aluminum cylinder probe. Texture analyzer in a double compression was carried out with $50 \%$ penetrate depth. The textural parameter considers the hardness $(\mathrm{N})$ and gumminess $(\mathrm{N})$ of bread. For textural measurements of each sample, central portion of two slices were cut from 3-4 different loaves (Angioloni \& Collar, 2011).

\subsection{Minerals assessment}

Samples were mineralized in hot air oven. Aliquots of $0.5 \pm 0.01 \mathrm{~g}$ of bread dry powder samples in $50 \mathrm{~mL}$ flasks were diluted with $10 \mathrm{~mL}$ of $\mathrm{HNO}_{3}$ and $5 \mathrm{~mL}$ of $\mathrm{HClO} 4$. Placed the solution in dark place for 24 hours and then kept in microwave oven for $30 \mathrm{~min}$. After cooling, the mineralized samples were added $25 \mathrm{~mL}$ distilled water in $100 \mathrm{~mL}$ bottle. A control sample also prepared for standard of $\mathrm{Na}, \mathrm{Mg}, \mathrm{Ca}, \mathrm{K}$ and $\mathrm{Zn}$ evaluated by atomic absorption spectrometry (Angioloni \& Collar, 2011).

\subsection{Sensory characteristics}

Bread incorporated with ginger powder were coded with different tags and submitted for sensory evaluation. A panel of twelve members was assigned to evaluate and rate the samples in comparison with controlled one. The bread samples were evaluated for crust and crumb color, texture, taste, aroma and overall acceptability on Nine-point Hedonic scale (Hooda \& Jood, 2005).

\subsection{Statistical analysis}

Analysis of variance was conducted to evaluate the significant observations and interactive results followed by Least Significant 
Difference (LSD) test to identify the significant differences among means $(\mathrm{P}<0.05)$, using statistical software (SAS V.9.1, SAS Institute, NC, USA). The experimental results were compiled (triplicates) and interpreted in means with standard deviation.

\section{Results and discussion}

\subsection{Dough mixing and rheological characteristics}

The mixing and rheological attributes of dough supplemented with ginger powder at varying concentrations are presented in Table 1. Addition of increasing levels of ginger powder presented significant changes in water absorption of dough. The time of dough development was observed to increase with increasing percentage of ginger powder incorporation up to 8 percent in comparison with control sample. Dough stability changes gradually with increase in the incorporation of ginger powder and the highest dough stability was found in control sample. Mixing tolerance index was decreased with the addition of ginger powder and degree of softening was high in control sample. Increasing level of ginger powder incorporation exhibited proportional increased in water absorption percentage as compared to control (Table 1). The dough handling was uniform up to 4 percent incorporation of ginger powder and beyond this the dough become sticky. Likewise, Faheid (1999), reported their observations about the time of dough development of onion and garlic powder added flours. Similarly, garlic incorporated dough showed that dough stability on farinograph decreased while mixing tolerance index increased (Venkateswara Rao et al., 1992).

Water absorption of ginger supplemented dough was used as indicator of mixing property. The outcomes shown that the presence of ginger had obvious effect on dough mixing properties (Table 1). Replacement of ginger powder mainly enhanced water absorption at increasing percentage of ginger powder. Wheat flour contains optimum protein content that is also associated with water absorption of dough. On contrary, dough development time was not reduced as significantly as was reported by Chauhan et al. (1992). High dough stability helps in optimizing the dough for better rheological properties in proofing and baking. Similar pattern was reported by AbouZaid et al. (2012) on water absorption of fibers incorporated in wheat flour. Likewise, the addition of wheat flour in chickpea flour raised the water absorption (Mohammed et al., 2012). Moreover, hydration capacity of water also increased water absorption of wheat flour (Moniem \& Yaseen, 1993).

The Mixolab analysis refer the explanation of physicochemical response of wheat dough subjected to temperature and mixing. The mechanical changes due to mixing and heating were elaborated in mixolab measurements Table 1. A typical Mixolab curve for control and ginger powder supplemented dough showing several stages pertaining to dough changes due to mixing force and dual temperatures. At the start of mixing, the dispersal of material and hydration of flour compounds occurred following the homogenous distribution of primary spherical protein particles. It caused the development of three-dimensional viscoelastic structure with gas retention properties (Aussenac et al., 2001). Rise in torque $\left(C_{1}\right)$ was noticed till the maximum reached and then dough was resisted the deformation for a while. The persistent torque determined the stability of dough.
The dough properties ranged from smooth and elastic to sticky and slack under the influence of mixing (Sliwinski et al., 2004). Second stage $\left(C_{s}\right)$ showed the reduction in torque resulting in weakening of protein. Third stage $\left(\mathrm{C}_{2}\right)$ was found in further reduction of torque due to the mutual effect of mechanical shear stress and temperature. This stage is linked to initiation of protein unfolding or breakdown and destabilization. Lowest torque was observed at $45-52^{\circ} \mathrm{C}$ related to further changes in protein due to variations and modification in starch physicochemical properties. Destabilization and unfolding of protein matrix during heating phase may cause facilitation of sulphidryl-disulphide reactions (Li \& Lee, 1998).

The differences in torque were due to gelatinization of starch and it occurs under the influence of temperature variations. Protein network weakening or breakdown ( $\alpha$ ), gelatinization rate $(\beta)$ and cooking stability rate $(\lambda)$ were indicated as $(\mathrm{Nm} / \mathrm{min})$ in Table 1. increased from 0.190- by the addition of ginger powder supplemented flour (Table 1).

Increase in temperature resulted in the shift of protein to secondary place due to starch gelatinization which also cause variations in torque at $\mathrm{C}_{3}$ or fourth stage. Hydration of starch granules at this stage occurred and cause swelling of molecules. Leaching of amylose chains promoted the rise in torque due to increased viscosity. This rise in torque continues until the mechanical shear stress and temperature lead to the physical breakdown of starch granules associated in the reduction of viscosity at $\mathrm{C}_{4}$ (fifth stage). This breakdown is directly linked to the cooking of starch (Rojas et al., 1999). At the last stage $\left(\mathrm{C}_{5}\right.$, sixth stage $)$ increase in dough resistance cause decrease in torque due to decrease in temperature. The results were matched with the results of Koksel et al. (2009), whereby starch gelling capacity enhanced in different genotypes of wheat compared with wheat flour. The $\mathrm{C}_{5}$ value was ranged from $2.70 \mathrm{Nm}$ to $3.59 \mathrm{Nm}$ in different genotypes wheat flours.

\subsection{Mixograph profiler index}

It can be seen the ranking of index in Figure la-e defined by Mixolab Profiler: Water absorption index (absorption potential), Mixing index or dough behavior at $30^{\circ} \mathrm{C}$ during mixing, Gluten+ index or behavior of the gluten after heating the dough, maximum viscosity during heating which relies on both starch quality (viscosity index) and amylase activity (amylolysis index), the ability to withstand amylolysis and retrogradation index (starch retrogradation).

The maximum value of the Gluten+ index and Mixing index corresponds to high gluten resistance to heating with more dough stability in mixing, respectively. The high dough viscosity corresponds to high value of viscosity index during heating. On the other hand, the high values of Retrogradation index and the Amylolysis index corresponds to low amylase activity, ultimately the low shelf life of end product (Chopin Applications Laboratory, 2009). Comparing with the control sample, it can be observed that mixing index is higher in the case of flour with $8 \%$ ginger powder but with low Gluten+ index. Gluten index reduced from $96 \%$ to $90 \%$ with the rise in wheat bran stream incorporated in wheat flour. This parameter gives information both on quality 


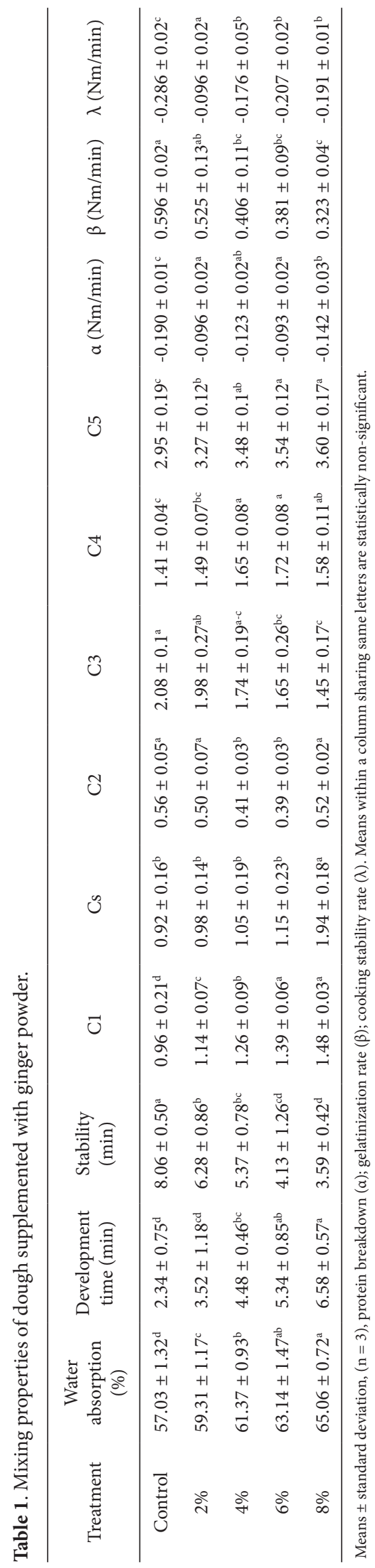




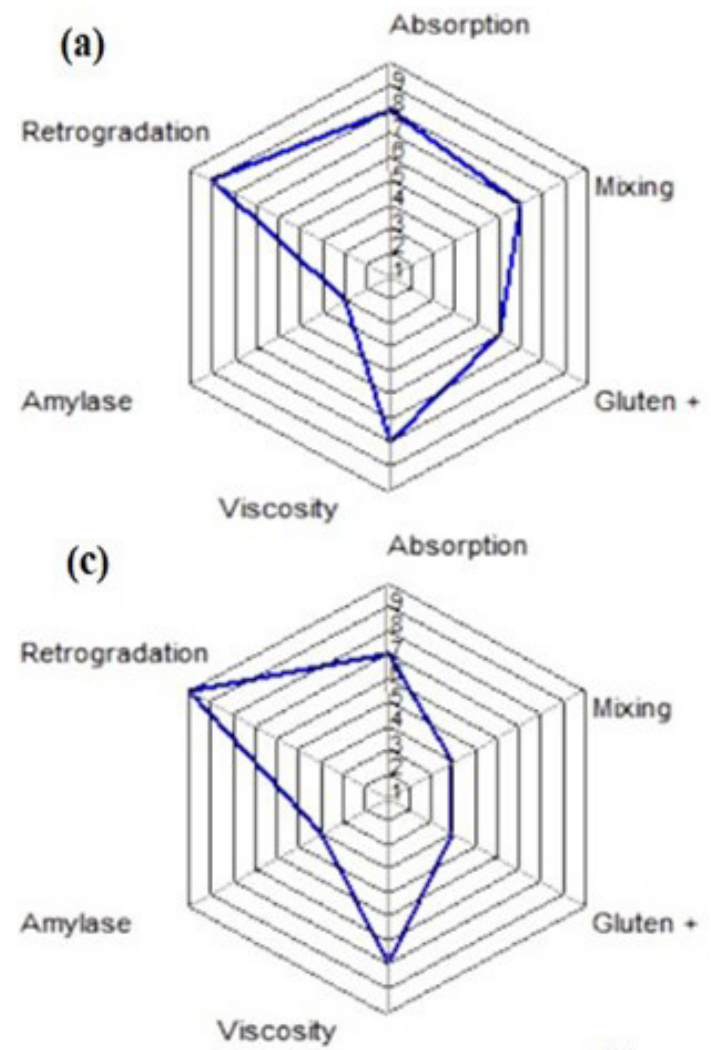

(e)

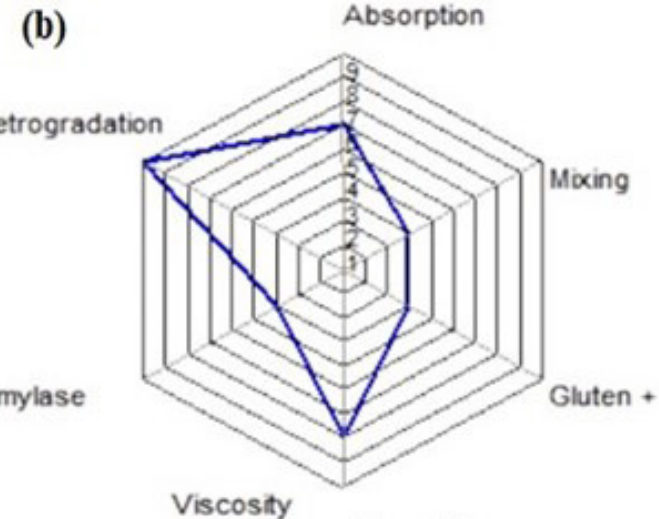

(d)

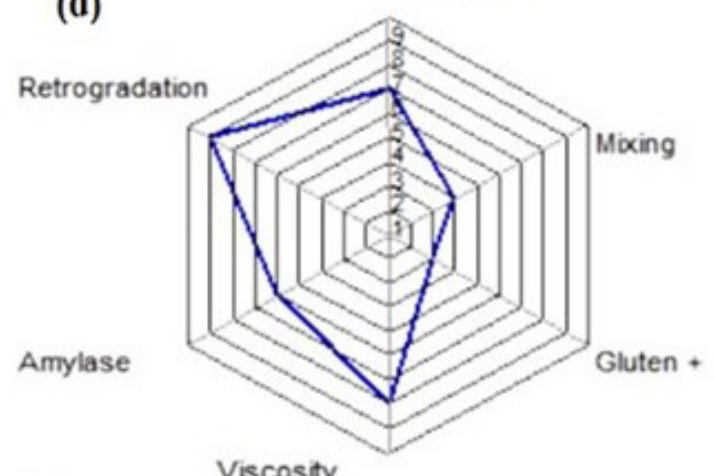

Absorption

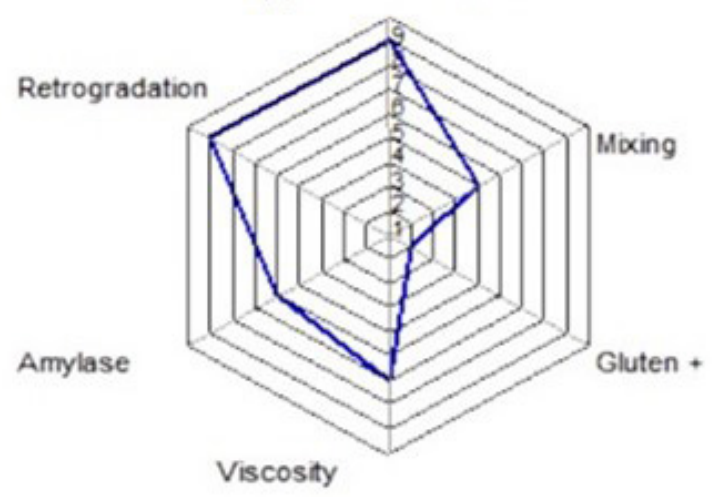

Figure 1. Mixograph profiler index of wheat flour; (a) without ginger powder (0\%), (b) $2 \%$ ginger powder (c) $4 \%$ ginger powder (d) $6 \%$ ginger powder (e) $8 \%$ ginger powder.

and quantity of gluten and is generally based on the ratio of low/high molecular weight proteins (Iuliana et al., 2012). High gluten index suggests superior share of high molecular weight proteins exist in gluten (Collar et al., 2007).

Whereas the higher viscosity index and retrogradation index were noticed for control sample with $0 \%$ ginger enrichment and highest Amylase index was observed for $2 \%$ ginger powder enriched flour. Optimum viscosity during heating depends on both starch quality and amylase activity (viscosity index), starch ability to withstand starch retrogradation (retrogradation index) and amylolysis/amylolysis index (Iuliana et al., 2012). The highest value of viscosity index is associated with the high viscosity of dough during heating, whereas the high values of the Retrogradation index and Amylolysis index relates to the low shelf life of the product and low amylase activity.

\subsection{Texture analysis}

Texture is the quality of bread that defined by feel, touch and includes overall aesthetic value of bread (Bhat et al., 2015) Starting from the hardness of bread it observed that hardness was significantly increased by addition of ginger powder depending upon the level of concentration. A linear trend was noticed with increasing percentage of ginger powder and maximum hardness $41.83 \mathrm{~N}$, gumminess $34.21 \mathrm{~N}$ and chewiness $24.31 \mathrm{~N}$ was recorded at $8 \%$ ginger powder while the lowest result observed for controlled samples $(17.32 \mathrm{~N}, 18.41 \mathrm{~N}, 9.31 \mathrm{~N})$ as indicated in Table 2. Sample with $6 \%$ ginger powder recorded $31.92 \mathrm{~N}$ hardness, gumminess $27.81 \mathrm{~N}$ and chewiness $19.61 \mathrm{~N}$ whereas non-significant values were noted for $2 \%$ and $4 \%$ ginger powder. This study was in agreement with the findings of Angioloni \& Collar, (2011) showed the range of bread hardness of various 
samples from $13 \mathrm{~N}$ for wheat bread and $139 \mathrm{~N}$ for buckwheat sample. Moreover, rye, oat, spelt wheat and kamut wheat bread indicated $51 \mathrm{~N}, 38 \mathrm{~N}, 31 \mathrm{~N}$ and $36 \mathrm{~N}$ respectively (Angioloni \& Collar, 2011). The increased in hardness was due to high fibrous composition of buckwheat. Similar results were observed by (Kumar \& Kumar, 2011).

\subsection{Total phenolic content}

Total phenolic content (mg GAE/100 g DW) along with radical scavenging activity in terms of percent $\mathrm{DPPH}$ for ginger supplemented bread samples was described in Table 3. The results depicted that phenolic content were significant and considerably increased with the addition of ginger powder at various levels. A liner increasing trend was observed for phenolic content (24.6) for control sample following the 29.31, 36.91, 43.16 and $51.34 \mathrm{mg} \mathrm{GAE} 100 \mathrm{~g}^{-1} \mathrm{DW}$ for $2 \%, 4 \%, 6 \%$ and $8 \%$ respectively.

Percent inhibition of radical scavenging activity (DPPH) was found to be increased gradually at increasing level of ginger powder (27.43-47.23\%). Similar trend was reported by Pekmez \& Yilmaz (2018) for flat bread enriched with black carrot fiber content at different levels. The given outcomes are also in accordance with the findings of Konrade \& Klava (2017) an increasing trend of phenolic content in crispbread by adding carrot, pumpkin and apple dry extracts. Total phenolic content in fresh carrot were always higher than dried form (microwave and sundried). The

Table 2. Textural properties of ginger supplemented bread at various levels.

\begin{tabular}{cccc}
\hline Treatment & Hardness $(\mathrm{N})$ & Gumminess $(\mathrm{N})$ & Chewiness $(\mathrm{N})$ \\
\hline Control & $17.32 \pm 1.7^{\text {de }}$ & $18.41 \pm 1.3^{\mathrm{e}}$ & $9.31 \pm 1.2^{\mathrm{de}}$ \\
$2 \%$ & $21.37 \pm 2.1^{\mathrm{d}}$ & $21.94 \pm 1.21^{\mathrm{cd}}$ & $12.56 \pm 1.56^{\mathrm{d}}$ \\
$4 \%$ & $29.25 \pm 2.3^{\mathrm{c}}$ & $25.18 \pm 2.13^{\mathrm{c}}$ & $16.69 \pm 1.7^{\mathrm{bc}}$ \\
$6 \%$ & $31.92 \pm 2.6^{\mathrm{b}}$ & $27.81 \pm 1.8^{\mathrm{b}}$ & $19.61 \pm 1.4^{\mathrm{b}}$ \\
$8 \%$ & $41.83 \pm 2.3^{\mathrm{a}}$ & $34.21 \pm 1.7^{\mathrm{a}}$ & $24.31 \pm 2.9^{\mathrm{a}}$ \\
\hline
\end{tabular}

Means \pm standard deviation.

Table 3. Total Phenolic Content and scavenging activity of ginger supplemented bread.

\begin{tabular}{lcc}
\hline \multicolumn{1}{c}{ Treatment } & $\begin{array}{c}\text { TPC } \\
(\mathrm{mg} \mathrm{GAE} / 100 \mathrm{~g} \mathrm{DW})\end{array}$ & DPPH (\%) \\
\hline Control & $24.6 \pm 1.7^{\mathrm{e}}$ & $27.43 \pm 7.98^{\mathrm{e}}$ \\
$2 \%$ & $29.31 \pm 1.3^{\mathrm{d}}$ & $31.72 \pm 4.03^{\mathrm{b}}$ \\
$4 \%$ & $36.91 \pm 2.1^{\mathrm{c}}$ & $36.74 \pm 7.58^{\mathrm{c}}$ \\
$6 \%$ & $43.16 \pm 1.4^{\mathrm{b}}$ & $43.12 \pm 4.05^{\mathrm{cd}}$ \\
$8 \%$ & $51.34 \pm 1.7^{\mathrm{a}}$ & $47.23 \pm 14.09^{\mathrm{a}}$ \\
\hline
\end{tabular}

Means \pm standard deviation. reduction could be due to thermal treatments (Rickman et al., 2007; Ruiz-Rodriguez et al., 2008).

The results also showed agreement with findings reported by Balestra et al. (2011) that TPC raised in bread samples by the addition of ginger powder. The highest value $(0.485 \mathrm{mg}$ GAE/g DW) was recorded in $6 \%$ ginger powder bread and minimum value showed in $0 \%(0.143 \mathrm{mg} \mathrm{GAE} / \mathrm{g} \mathrm{DW})$ ginger powder bread. Similar results reported by Almasodi (2018) and Konrade \& Klava, (2017) whereby TPC of bread was increased by the addition of ginger flour.

\subsection{Mineral analysis}

Significant results were noticed for the mineral analysis of ginger enriched bread as depicted in Table 4. Increasing percentage of ginger powder (8\%) was resulted in optimum mineral contents such as $\mathrm{Na}$ (451.69 mg/kg), Ca (127.32 mg/kg), K (427.61 mg/kg), $\mathrm{Fe}(15.19 \mathrm{mg} / \mathrm{kg}), \mathrm{Zn}(7.04 \mathrm{mg} / \mathrm{kg})$ and $\mathrm{Cu}$ (3.47) respectively. Whereas the controlled sample exhibited lower values for all the minerals as presented in Table 4. Same trend was also reported by Bolarinwa et al. (2019) by adding the moringa seed powder in bread samples with $\mathrm{K}(224 \mathrm{mg} / \mathrm{kg}), \mathrm{Ca}(334 \mathrm{mg} / \mathrm{kg})$ and $\mathrm{Fe}$ $(13.9-26.4 \mathrm{mg} / \mathrm{kg})$. Supplementation of wheat bread with different varieties of mushroom powder resulted in optimum level of $\mathrm{Na}$ (32.50-63.81 mg/g) as reported by (Oyetayo \& Oyedeji, 2017). Similary, Winiarska-Mieczan \& Kwiecień, (2011) suggested that the addition of pumpkin flour in wheat bread resulted in $\mathrm{Na}$ content (461.9 $\mathrm{mgkg}^{-1}$ ) compared without pumpkin powder $\left(423.1 \mathrm{mgkg}^{-1}\right)$. Similar trend was noticed for $\mathrm{Cu}\left(0.1-0.3 \mathrm{mgkg}^{-1}\right)$ and $\mathrm{Zn}\left(0.6-1.1 \mathrm{mgkg}^{-1}\right)$ in bread fortified with rye, oat and buckwheat (Angioloni \& Collar 2011).

\subsection{Sensorial properties}

Mean square values of bread assessed on nine-point hedonic scale were showed in Table 5 . It observed that $2 \%$ and $4 \%$ ginger powder bread showed satisfactory color score. Texture of bread slices was gradually changed with increasing percentage of ginger powder incorporation. Significant results were noticed in control sample while $2 \%$ and $4 \%$ ginger powder bread indicated acceptable score of texture. Moreover, $6 \%$ and $8 \%$ ginger powder bread showed unacceptable score of texture. Crumb color score of bread samples were significantly reduced by the addition of ginger powder. The minimum values indicated in $8 \%$ and $6 \%$ ginger powder bread ( 4.67 and 5.33), respectively. The acceptable aroma was noticed in $0 \%, 2 \%$ and $4 \%$ ginger powder bread, whereby $6 \%$, and $8 \%$ ginger powder breads showed unsatisfactory aroma of bread. The taste of bread was significantly decreased

Table 4. Mineral content $(\mathrm{mg} / \mathrm{kg})$ of ginger supplemented bread at various levels.

\begin{tabular}{|c|c|c|c|c|c|c|}
\hline Treatment & $\mathrm{Na}$ & $\mathrm{Ca}$ & $\mathbf{K}$ & $\mathrm{Fe}$ & $\mathrm{Zn}$ & $\mathrm{Cu}$ \\
\hline Control & $409.13 \pm 3.6^{\mathrm{e}}$ & $98.17 \pm 6.7^{\mathrm{e}}$ & $219.63 \pm 8.3^{\mathrm{e}}$ & $3.47 \pm 1.2^{\mathrm{f}}$ & $1.92 \pm 0.4^{\mathrm{d}}$ & $1.12 \pm 0.3^{c}$ \\
\hline $2 \%$ & $418.32 \pm 7.1^{\mathrm{d}}$ & $106.73 \pm 1.7^{\mathrm{d}}$ & $271.92 \pm 7.1^{\mathrm{d}}$ & $7.14 \pm 0.6^{\mathrm{de}}$ & $2.31 \pm 0.2^{\mathrm{c}}$ & $1.42 \pm 0.7^{c}$ \\
\hline $4 \%$ & $426.31 \pm 4.3^{c}$ & $114.27 \pm 3.9^{b c}$ & $324.31 \pm 6.1^{\mathrm{c}}$ & $8.12 \pm 0.9^{c}$ & $2.83 \pm 0.3^{c}$ & $1.63 \pm 0.1 c$ \\
\hline $6 \%$ & $439.31 \pm 2.7^{b}$ & $118.21 \pm 5.1^{b}$ & $378.37 \pm 7.3^{\mathrm{b}}$ & $12.57 \pm 0.4^{\mathrm{ab}}$ & $4.81 \pm 0.6^{\mathrm{b}}$ & $2.06 \pm 0.4^{\mathrm{b}}$ \\
\hline $8 \%$ & $451.69 \pm 6.3^{\mathrm{a}}$ & $127.32 \pm 2.9^{a}$ & $427.61 \pm 2.7^{\mathrm{a}}$ & $15.19 \pm 0.7^{a}$ & $7.04 \pm 0.9^{\mathrm{a}}$ & $3.47 \pm 0.2^{\mathrm{a}}$ \\
\hline
\end{tabular}

Means \pm standard deviation. 
Table 5. Effect of ginger powder supplementation on sensorial properties of bread.

\begin{tabular}{ccccccc}
\hline Treatment & Crust color & Texture & Crumb color & Aroma & $\begin{array}{c}\text { Taste } \\
\text { acceptability }\end{array}$ \\
\hline Control & $7.67 \pm 1.53^{\mathrm{a}}$ & $7.33 \pm 1.15^{\mathrm{a}}$ & $8.0 \pm 1.00^{\mathrm{a}}$ & $8.33 \pm 0.58^{\mathrm{a}}$ & $8.33 \pm 1.00^{\mathrm{a}}$ & $7.67 \pm 1.53^{\mathrm{a}}$ \\
$2 \%$ & $7.0 \pm 1.00^{\mathrm{ab}}$ & $6.67 \pm 1.53^{\mathrm{ab}}$ & $7.33 \pm 0.58^{\mathrm{ab}}$ & $7.0 \pm 1.00^{\mathrm{ab}}$ & $7.21 \pm 0.58^{\mathrm{ab}}$ & $7.0 \pm 1.00^{\mathrm{ab}}$ \\
$4 \%$ & $6.33 \pm 1.15^{\mathrm{ab}}$ & $5.33 \pm 0.58^{\mathrm{bc}}$ & $6.0 \pm 1.03^{\mathrm{bc}}$ & $5.67 \pm 1.15^{\mathrm{bc}}$ & $5.19 \pm 1.03^{\mathrm{b}}$ & $5.67 \pm 0.58^{\mathrm{bc}}$ \\
$6 \%$ & $5.67 \pm 0.58^{\mathrm{bc}}$ & $4.0 \pm 1.00^{\mathrm{c}}$ & $5.33 \pm 0.58^{\mathrm{c}}$ & $4.33 \pm 1.53^{\mathrm{c}}$ & $4.67 \pm 1.53^{\mathrm{b}}$ & $4.33 \pm 1.15^{\mathrm{cd}}$ \\
$8 \%$ & $4.0 \pm 1.04^{\mathrm{c}}$ & $3.67 \pm 0.58^{\mathrm{c}}$ & $4.67 \pm 1.53^{\mathrm{c}}$ & $3.67 \pm 1.15^{\mathrm{c}}$ & $3.52 \pm 1.02^{\mathrm{c}}$ & $3.0 \pm 1.02^{\mathrm{d}}$ \\
\hline
\end{tabular}

Means sharing same letters within a column are non-significant with $\mathrm{p} \leq 0.05(\mathrm{n}=3)$.

by addition of ginger powder. Bread enriched with $0 \%, 2 \%$ and $4 \%$ ginger powder presented acceptable taste compared with $6 \%$ and $8 \%$. Overall acceptability indicated the acceptability of $2 \%$ and $4 \%$ ginger enriched bread was most recommended qualitatively by the panelist.

These results were in agreement with the results obtained by Almasodi, 2018. These results showed compliance with the findings of Bolarinwa et al. (2019), whereby fortification of moringa seed powder in bread was ranged from $5 \%$ to $20 \%$. Similar results showed in the research of Song et al. (2016). In this study, black carrot flour was added in the sponge cake with the $(0 \%$ to $9 \%)$. The results showed $6 \%$ black carrot cake was acceptable as judged by panelists, while other black carrot cakes were unsatisfactory.

\section{Conclusion}

Supplementation of ginger powder in wheat bread was useful and efficient approach to get good quality of bread. The study of using various ginger powder fractions in bread concluded that $2-4 \%$ of ginger powder was found to be effective for good rheological properties, texture, antioxidant properties as well as minerals. This study was also helpful in exploring the nutritional quality of baked goods with efficient use of vegetable powders for value addition of various food stuff.

\section{References}

Abou-Zaid, A. A. M., El-Bandy, M. A. S., \& Ismaeil, H. (2012). Rheological properties and quality evaluation of pan bread and biscuits supplemented with mushroom micelles flours. Australian Journal of Basic and Applied Sciences, 6(6), 237-245.

Ali, B. H., Blunden, G., Tanira, M. O., \& Nemmar, A. (2008). Some phytochemical, pharmacological and toxicological properties of ginger (Zingiber officinale Roscoe): a review of recent research. Food and Chemical Toxicology, 46(2), 409-420. http://dx.doi.org/10.1016/j. fct.2007.09.085. PMid:17950516.

Almasodi, A. G. S. (2018). Production and evaluation of some bakery products containing ginger powder. Journal of Food and Nutrition Research, 6(4), 205-215. http://dx.doi.org/10.12691/jfnr-6-4-2.

Angioloni, A., \& Collar, C. (2011). Nutritional and functional added value of oat, Kamut ${ }^{\oplus}$, spelt, rye and buckwheat versus common wheat in breadmaking. Journal of the Science of Food and Agriculture, 91(7), 1283-1292. http://dx.doi.org/10.1002/jsfa.4314. PMid:21337578.

Aussenac, T., Carceller, J. L., \& Kleiber, D. (2001). Changes in SDS solubility of glutenin polymers during dough mixing and resting. Cereal Chemistry, 78(1), 39-45. http://dx.doi.org/10.1094/ CCHEM.2001.78.1.39.
Bailey-Shaw, Y. A., Williams, L. A., Junor, G. A. O., Green, C. E., Hibbert, S. L., Salmon, C. N., \& Smith, A. M. (2008). Changes in the contents of oleoresin and pungent bioactive principles of Jamaican ginger (Zingiber officinale Roscoe.) during maturation. Journal of Agricultural and Food Chemistry, 56(14), 5564-5571. http://dx.doi. org/10.1021/jf072782m. PMid:18564850.

Balestra, F., Cocci, E., Pinnavaia, G., \& Romani, S. (2011). Evaluation of antioxidant, rheological and sensorial properties of wheat flour dough and bread containing ginger powder. Lebensmittel-Wissenschaft + Technologie, 44(3), 700-705. http://dx.doi.org/10.1016/j.lwt.2010.10.017.

Bhat, J., Afzal, S., Gull, A., Haq, R. U., \& Safapuri, T. A. (2015). Textural and sensory characteristics of bread made from wheat flour supplemented with water chestnut. American Journal of Food Science and Nutrition Research, 2(3), 94-97.

Bolarinwa, I. F., Aruna, T. E., \& Raji, A. O. (2019). Nutritive value and acceptability of bread fortified with moringa seed powder. Journal of the Saudi Society of Agricultural Sciences, 18(2), 195-200. http:// dx.doi.org/10.1016/j.jssas.2017.05.002.

Chan, E. W. C., Lim, Y. Y., Wong, L. F., Lianto, F. S., Wong, S. K., Lim, K. K., Joe, C. E., \& Lim, T. Y. (2008). Antioxidant and tyrosinase inhibition properties of leaves and rhizomes of ginger species. Food Chemistry, 109(3), 477-483. http://dx.doi.org/10.1016/j. foodchem.2008.02.016.

Chauhan, G. S., Zillman, R. R., \& Eskin, N. A. M. (1992). Dough mixing and breadmaking properties of quinoa-wheat flour blends. International Journal of Food Science \& Technology, 27(6), 701-705. http://dx.doi.org/10.1111/j.1365-2621.1992.tb01241.x.

Chopin Applications Laboratory. (2009). Mixolab applications handbook. Rheological and enzymatic analysis. France: Villeneuve la Garenne.

Collar, C., Bollain, C., \& Rosell, C. M. (2007). Rheological behaviour of formulated bread doughs during mixing and heating. Food Science \& Technology International, 13(2), 99-107. http://dx.doi. org/10.1177/1082013207078341.

Faheid, S. M. M. (1999). Studies on onion and garlic bread. Deut Lebensm-Rundsch, 95, 17-22.

Hadnađev, T. D., Torbica, A., \& Hadnađev, M. (2011). Rheological properties of wheat flour substitutes/alternative crops assessed by Mixolab. Procedia Food Science, 1, 328-334. http://dx.doi.org/10.1016/j. profoo.2011.09.051.

Hathorn, C. S., Biswas, M. A., Gichuhi, P. N., \& Bovell-Benjamin, A. C. (2008). Comparison of chemical, physical, micro-structural, and microbial properties of breads supplemented with sweetpotato flour and high-gluten dough enhancers. Lebensmittel-Wissenschaft + Technologie, 41(5), 803-815. http://dx.doi.org/10.1016/j.lwt.2007.06.020.

Hooda, S., \& Jood, S. (2005). Organoleptic and nutritional evaluation of wheat biscuits supplemented with untreated and treated fenugreek flour. Food Chemistry, 90(3), 427-435. http://dx.doi.org/10.1016/j. foodchem.2004.05.006. 
Iuliana, B., Georgeta, S., Sorina, I. V., \& Iuliana, A. (2012). Effect of the addition of wheat bran stream on dough rheology and bread quality. The Annals of the University Dunarea de Jos of Galati. Fascicle VI, Food Technology, 36(1), 39-52.

Kelebek, H., Selli, S., Canbas, A., \& Cabaroglu, T. (2009). HPLC determination of organic acids, sugars, phenolic compositions and antioxidant capacity of orange juice and orange wine made from a Turkish cv. Kozan. Microchemical Journal, 91(2), 187-192. http:// dx.doi.org/10.1016/j.microc.2008.10.008.

Koksel, H., Kahraman, K., Sanal, T., Ozay, D. S., \& Dubat, A. (2009). Potential utilization of mixolab for quality evaluation of bread wheat genotypes. Cereal Chemistry, 86(5), 522-526. http://dx.doi. org/10.1094/CCHEM-86-5-0522.

Konrade, D., \& Klava, D. (2017). Total content of phenolics and antioxidant activity in crispbreads with plant by-product addition. Rural Sustainability Research, 38(333), 24-31. http://dx.doi.org/10.1515/ plua-2017-0009.

Ktenioudaki, A., \& Gallagher, E. (2012). Recent advances in the development of high-fiber baked products. Trends in Food Science \& Technology, 28(1), 4-14. http://dx.doi.org/10.1016/j.tifs.2012.06.004.

Kumar, N., \& Kumar, K. (2011). Development of carrot pomace and wheat flour-based cookies. Journal of Pure and Applied Science and Technology, 1(1), 5-11.

Li, M., \& Lee, T. C. (1998). Effect of cysteine on the molecular weight distribution and the disulfide cross-link of wheat flour proteins in extrudates. Journal of Agricultural and Food Chemistry, 46(3), 846-853. http://dx.doi.org/10.1021/jf960825l.

Mohammed, I., Ahmed, A. R., \& Senge, B. (2012). Dough rheology and bread quality of wheat-chickpea flour blends. Industrial Crops and Products, 36(1), 196-202. http://dx.doi.org/10.1016/j. indcrop.2011.09.006.

Moniem, G. A., \& Yaseen, A. A. (1993). High dietary fiber cookies from several sources of bran or husk. Egyptian Journal of Food Science, 21(2), 157-170.

Oyetayo, V. O., \& Oyedeji, R. R. (2017). Proximate and mineral composition of bread fortified with mushroom (Plerotus ostreatus and Calocybe indica). Microbiology Research Journal International, 19(4), 1-9. http://dx.doi.org/10.9734/MRJI/2017/32133.

Pekmez, H., \& Yılmaz, B. B. (2018). Quality and antioxidant properties of black carrot (Daucus carota ssp. sativus var. atrorubens Alef.) fiber fortified flat bread (Gaziantep Pita). Journal of Agricultural Science and Technology B, 8, 522-529.
Peressini, D., \& Sensidoni, A. (2009). Effect of soluble dietary fibre addition on rheological and breadmaking properties of wheat doughs. Journal of Cereal Science, 49(2), 190-201. http://dx.doi. org/10.1016/j.jcs.2008.09.007.

Rickman, J. C., Barrett, D. M., \& Bruhn, C. M. (2007). Nutritional comparison of fresh, frozen and canned fruits and vegetables. Part 1. Vitamins $\mathrm{C}$ and $\mathrm{B}$ and phenolic compounds. Journal of the Science of Food and Agriculture, 87(6), 930-944. http://dx.doi.org/10.1002/jsfa.2825.

Rojas, J. A., Rosell, C. M., \& De Barber, C. B. (1999). Pasting properties of different wheat flour-hydrocolloid systems. Food Hydrocolloids, 13(1), 27-33. http://dx.doi.org/10.1016/S0268-005X(98)00066-6.

Ruiz-Rodriguez, A., Marín, F. R., Ocaña, A., \& Soler-Rivas, C. (2008). Effect of domestic processing on bioactive compounds. Phytochemistry Reviews, 7(2), 345-384. http://dx.doi.org/10.1007/s11101-007-9073-1.

Sangwan, A., Kawatra, A., \& Sehgal, S. (2014). Nutritional composition of ginger powder prepared using various drying methods. Journal of Food Science and Technology, 51(9), 2260-2262. http://dx.doi. org/10.1007/s13197-012-0703-2. PMid:25190894.

Shirin Adel, P. R., \& Jamuna, P. (2010). Chemical composition and antioxidant properties of ginger root (Zingiber officinale). Journal of Medicinal Plants Research, 4(24), 2674-2679. http://dx.doi. org/10.5897/JMPR09.464.

Sliwinski, E. L., Kolster, P., \& Van Vliet, T. (2004). On the relationship between large-deformation properties of wheat flour dough and baking quality. Journal of Cereal Science, 39(2), 231-245. http:// dx.doi.org/10.1016/j.jcs.2003.10.005.

Song, K., Hyeonbin, O., Zhang, Y., \& Kim, Y. (2016). Quality characteristics and antioxidant properties of sponge cakes containing black carrot (Daucus carota ssp. sativus var. atrorubens Alef) flour. Progress in Nutrition, 18(2), 176-183.

Venkateswara Rao, G., Savithri, G. D., \& Indrani, D. (1992). Studies on the use of garlic in bread. Journal of Food Science and Technology, $29,147-149$.

Winiarska-Mieczan, A., \& Kwiecień, M. (2011). Evaluation of the mineral composition of breadstuff and frequency its consumption. Acta Scientiarum Polonorum. Technologia Alimentaria, 10(4), 487495. PMid:22230930.

Young, H. Y., Liao, J. C., Chang, Y. S., Luo, Y. L., Lu, M. C., \& Peng, W. H. (2006). Synergistic effect of ginger and nifedipine on human platelet aggregation: a study in hypertensive patients and normal volunteers. The American Journal of Chinese Medicine, 34(4), 545-551. http://dx.doi.org/10.1142/S0192415X06004089. PMid:16883626. 